\title{
Enrichment and tissue distribution of heavy metals in horseshoe crabs from the Beihai coast of Beibu Gulf
}

\author{
Daoquan $\mathrm{Xu}^{1,2, a}$, Yinghui Wang ${ }^{1,3, b^{*}}$, Kefu $\mathrm{Yu}^{1,3, c}$, Jing Guo ${ }^{1,2, d}$, Zhiwei Xiao ${ }^{2}$ \\ , Wanguo $\mathrm{Ye}^{2, \mathrm{f}}$, Wenpeng $\mathrm{Jia}^{2, \mathrm{~g}}$ \\ ${ }^{1}$ Coral Reef Research Center, Guangxi University. Nanning 530004, China; \\ ${ }^{2}$ College of Environmental Science and Engineering, Guangxi University. Nanning 530004, China; \\ ${ }^{3}$ School of Marine Sciences, Guangxi University. Nanning 530004, China. \\ axdq_gxu@163.com, bwyh@gxu.edu.com, 'kefuyu@scsio.ac.cn, dguojing8925@126.com,

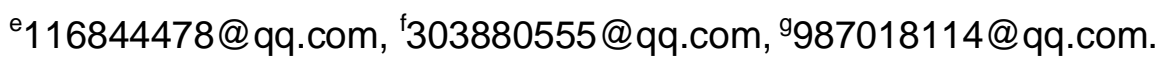

Keywords: Beibu Gulf; horseshoe crab; heavy metal; enrichment; tissue distribution

Abstract. The contents and distributions of some heavy metals i.e., $\mathrm{Cd}, \mathrm{Cu}, \mathrm{Pb}$ and $\mathrm{Zn}$ in different tissues of horseshoe crabs including Carcinoscorpins rotundicauda and Tachypleus tridentatus from the Beihai coast of Beibu Gulf were investigated. The results indicated that the variation tendency of measured metals in visceral mass was in the order of $\mathrm{Zn}>\mathrm{Cu}>\mathrm{Cd}>\mathrm{Pb}$, while that in other tissues including gill, carapace and muscle was all in the order of $\mathrm{Zn}>\mathrm{Cu}>\mathrm{Pb}>\mathrm{Cd}$; The metal contents in different tissues of the organisms were varied, and $\mathrm{Cd}, \mathrm{Cu}$ and $\mathrm{Zn}$ contents expressed the highest enrichment in the visceral mass, carapace and muscle, while the $\mathrm{Pb}$ content in the gill was relatively high. The spatial distributions of all metals in the organisms were significantly different; however, the spatial tendencies were not identical to each metal. Thus, further research should be taken to explore the relationship between organisms and environments.

\section{Introduction}

Beibu Gulf, located at the northwest of the South China Sea, is an important habitat and nesting ground for many rare marine organisms, e.g., Chinese white dolphin, dugong, and horseshoe crab. With the "Beibu Gulf development plan" in recent ten years and go on, industrialization and urbanization along the Beibu Gulf have led to more anthropogenic disturbance on natural ecosystem structure and environmental quality of the coastal region. Plenty of environmental problems have emerged, among which, heavy metal pollution remain as a major issue due to the toxicity, abundance, persistent and bio-accumulation [1]. Thus, as major environmental pollutants, the hazards of heavy metals on coastal ecosystem and biosafety have attracted the society's universal attention.

Horseshoe crabs are marine chelicerate arthropods and generally called as "living fossil" since they remarkably retain their genetic makeup and morphologically unchanged for more than 200 million years [2]. Horseshoe crabs due to their special characteristics own much scientific value in paleontology, evolutionary biology, bionics and medical researches et al [3]. Horseshoe crabs are typical coastal organism and heavy metal pollution has become a limiting factor of their survival and resource utilization. In the previous studies, the enrichments of heavy metals in the horseshoe crabs from southeastern Asia [2, 4] and eastern North America [5, 6] have been of much research. However, to date there has been little information published on the horseshoe crabs inhabiting Chinese waters including Beibu Gulf, which is an important habitat of $C$. rotundicauda and T. tridentatus in the world. Hence, this study was initiated to investigate the enrichments of heavy metals in different tissues of horseshoe crabs ( $C$. rotundicauda and T. tridentatus) from the Beihai coast of Beibu Gulf.

\section{Materials and methods}

Sample collection. Matured horseshoe crab (C. rotundicauda and T. tridentatus) samples were collected from five typical habitats from the Beihai coast of Beibu Gulf during July 2014. The five habitats were Lianzhou Bay (S1), Zhulin Saltern (S2), Beimu Town (S3), Shatian Town (S4) and Yingluo Bay (S5), respectively. Samples of C. rotundicauda were collected from the regions of 
S1-S5, while samples of $T$. tridentatus were collected from the regions of S2-S4. Collected samples were then placed into sealed polyethylene bags, and preserved under freezing condition $\left(-20^{\circ} \mathrm{C}\right)$ prior to the analysis.

Analytical methods. The collected samples were thawed at room temperature in the laboratory and appropriate samples were washed thoroughly with deionized water prior to the dissection. Samples were dissected and tissue sub-samples were taken out from visceral mass, gill, carapace and muscle, respectively. Prepared tissue samples were placed in Teflon vessels and digested by wet method with a mixture of $\mathrm{HNO}_{3}$ and $\mathrm{H}_{2} \mathrm{O}_{2}$. Then the solutions dissolved with $5 \%$ (v/v) $\mathrm{HNO}_{3}$ to a final volume of $50 \mathrm{~mL}$. Finally, the levels $(\mathrm{mg} / \mathrm{kg})$ of $\mathrm{Cd}, \mathrm{Cu}, \mathrm{Pb}$ and $\mathrm{Zn}$ for all samples were analyzed by Inductively Coupled Plasma Mass Spectrometry (ICP-MS, Agilent 7700e, USA).

Quality assurance/quality control. Method blank, duplicate determination and standard reference material were performed with the same treatment to ensure the quality assurance and quality control. Analytical precisions for parallel samples were within $\pm 10 \%$. Recovery rates for the metals in the standard reference material (GBW10024) ranged from 93 to $112 \%$. All reagents were of analytical grade and deionized water was used for the preparation of all reagents. The containers used in sampling and analytical procedures were washed by dilute nitric acid (5\% (v/v) $\left.\mathrm{HNO}_{3}\right)$, followed by deionized water, for the free of exogenous pollutants.

\section{Results and discussion}

Heavy metals in horseshoe crabs. The monitoring results of $w(\mathrm{Cd}), w(\mathrm{Cu}), w(\mathrm{~Pb})$ and $w(\mathrm{Zn})$ in different tissues (visceral mass, gill, carapace and muscle) of horseshoe crabs from the Beihai coast of Beibu Gulf are shown in Table 1. It could be seen that the enrichments of heavy metals in horseshoe crabs showed regular changes. The overall variation tendency of heavy metals in visceral mass was in the order of $\mathrm{Zn}>\mathrm{Cu}>\mathrm{Cd}>\mathrm{Pb}$, while that in other tissues including gill, carapace and muscle was all in the order of $\mathrm{Zn}>\mathrm{Cu}>\mathrm{Pb}>\mathrm{Cd}$.

Table 1 Contents $(\mathrm{mg} / \mathrm{kg})$ of heavy metals in different tissues of C. rotundicauda and T. tridentatus from the Beihai coast of Beibu Gulf

\begin{tabular}{llllll}
\hline & & $w /(\mathrm{mg} / \mathrm{kg})$ & & \\
\cline { 3 - 6 } & & $\mathrm{Cd}$ & $\mathrm{Cu}$ & $\mathrm{Pb}$ & $\mathrm{Zn}$ \\
\hline \multirow{4}{*}{ C. rotundicauda } & visceral mass & $1.41 \pm 0.50$ & $35.60 \pm 14.60$ & $0.60 \pm 0.28$ & $93.24 \pm 34.15$ \\
& gill & $0.09 \pm 0.06$ & $10.36 \pm 6.29$ & $1.59 \pm 1.53$ & $14.41 \pm 6.60$ \\
& carapace & $0.07 \pm 0.04$ & $13.25 \pm 4.63$ & $0.88 \pm 0.69$ & $22.78 \pm 9.82$ \\
& muscle & $0.15 \pm 0.10$ & $10.98 \pm 5.11$ & $0.51 \pm 0.46$ & $49.17 \pm 22.63$ \\
\hline \multirow{5}{*}{ T. tridentatus } & visceral mass & $1.40 \pm 0.69$ & $19.56 \pm 12.95$ & $0.68 \pm 0.34$ & $58.45 \pm 14.82$ \\
& gill & $0.15 \pm 0.06$ & $9.13 \pm 4.56$ & $1.35 \pm 0.57$ & $22.40 \pm 6.79$ \\
& carapace & $0.11 \pm 0.05$ & $15.28 \pm 5.32$ & $0.51 \pm 0.21$ & $29.91 \pm 12.81$ \\
& muscle & $0.31 \pm 0.27$ & $12.29 \pm 3.38$ & $0.79 \pm 0.44$ & $52.68 \pm 22.10$ \\
\hline
\end{tabular}

For the organisms, there are differences in the abilities of enrichment and toxic tolerant of various metals. The monitoring results of this study showed that $\mathrm{Cu}$ and $\mathrm{Zn}$ were widespread in all tissues. In fact, $\mathrm{Cu}$ and $\mathrm{Zn}$ are essential trace elements for organisms and their relatively high contents indicated the active absorption of $\mathrm{Cu}$ and $\mathrm{Zn}$ from environment. $\mathrm{Cu}$ and $\mathrm{Zn}$ are significant components of many enzymes in the organisms, therefore are important to maintain the normal metabolism of organisms. In addition, similar to some mollusks and crustaceans, horseshoe crabs select $\mathrm{Cu}$ to constitute their reduction system, as well as to transport oxygen in the blood [7]. Besides, $\mathrm{Cd}$ and $\mathrm{Pb}$ are non-essential trace elements for organisms, and their relatively low contents could reflect the metabolic difference of organisms and the influences from habitat environment. While horseshoe crabs obtained nutrients from habitats, they also adsorbed these non-essential trace elements, and then stored in the organisms. 
These elements could disturbance the function of enzyme, and finally damage the normal metabolism system of the organisms [8].

Tissue differences of heavy metals. There were significant tissue differences among heavy metals from horseshoe crabs (ANOVA, p<0.05) (Fig. 1). It could be seen that $w(\mathbf{C d}), w(\mathbf{C u})$ and $w(\mathrm{Zn})$ in the visceral mass of $C$. rotundicauda as well as $w(\mathrm{Cd}), w(\mathrm{Cu})$ in the visceral mass of T. tridentatus were significantly different from those in other tissues. The tissue distribution of $w(\mathrm{~Pb})$ was different, and $w(\mathrm{~Pb})$ in the gill was significantly higher than that in other tissues.
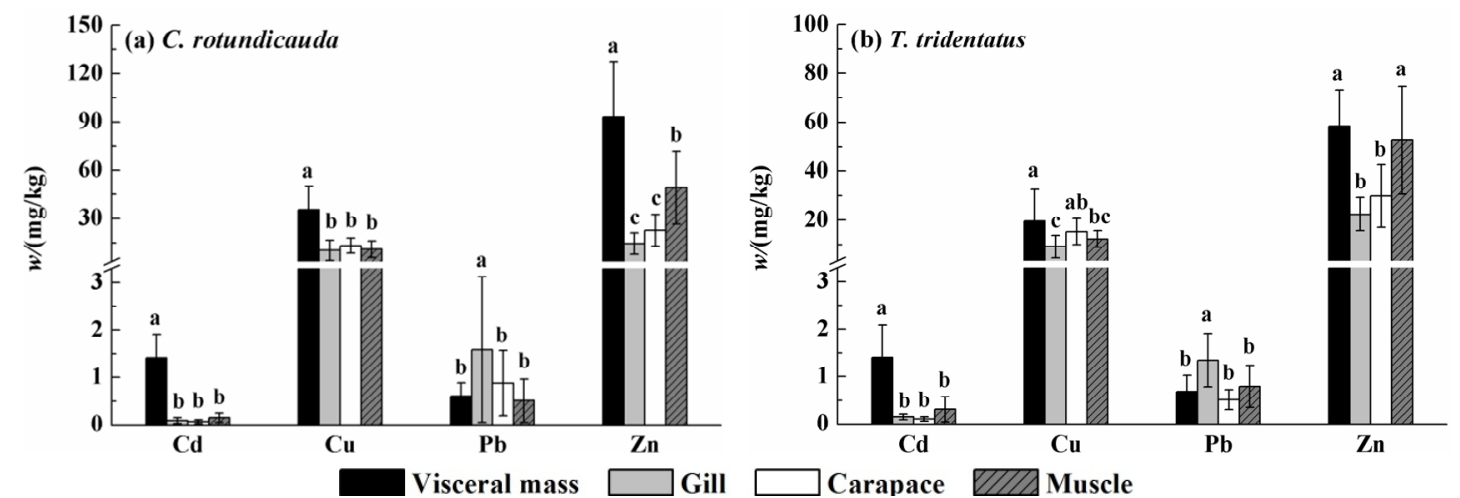

Fig.1 Contents (mg/kg) of heavy metals in various tissues of C. rotundicauda (a) and T. tridentatus (b) from the Beihai coast of Beibu Gulf

(The different letters in the same metal had significant difference, $\mathrm{p}<0.05$ )

Visceral mass is an internal organ composing by digestive tract, liver, kidney et al., which directs food digestion, absorption of nutrients and accumulation of toxic substances. Through above analysis, it could be seen that the enrichments of $\mathrm{Cd}, \mathrm{Cu}$ and $\mathrm{Zn}$ in visceral mass were significantly stronger than those in other tissues, and this might be due to the induction of metallothioneins (MTs) in the visceral mass. MTs are a group of metal-binding proteins of low molecular weight and rich cysteine, with the biological function to store metal ions and detoxicate in the organisms [9]. In addition, gill is also an important tissue in enriching some metals. When the organisms breath in water, gill plays an important role in filtering, during this process, free metal ions as well as particulate metals in water are likely to be combined with gill secretions, sticking in gill gap. The monitoring results of this study showed that the $\mathrm{Pb}$ enrichment in gill was significantly stronger than that in other tissues. Hence, the functional and metabolic differences of each tissue in the horseshoe crabs will affect the distributions of heavy metals in the organisms, and then result in the tissue differences of heavy metals.

Spatial differences of heavy metals. Affecting by the habitat environment, there were significant spatial differences for all measured metals. Thus, in this study, the spatial distributions of measured metals in the horseshoe crabs were discussed, taking the example of the visceral mass, which is an important target tissue of metal enrichment (ANOVA, p<0.05) (Fig. 2).

For the visceral mass of $C$. rotundicauda, $w(\mathrm{Cd})$ in $\mathrm{S} 2$ were significantly lower than that in other four regions; $w(\mathrm{Cu})$ in $\mathrm{S} 5$ showed significant difference from that in $\mathrm{S} 2, \mathrm{~S} 3$ and $\mathrm{S} 4$, while was no significantly different from that in $\mathrm{S} 1 ; w(\mathrm{~Pb})$ and $w(\mathrm{Zn})$ in $\mathrm{S} 3$ were significantly different from those in S1, S2 and S5, while showed no significant difference from those in S4. For the visceral mass of $T$. tridentatu, $w(\mathrm{Cd})$ and $w(\mathrm{~Pb})$ in $\mathrm{S} 4$ as well as $w(\mathrm{Cu})$ in $\mathrm{S} 2$ were significantly higher than those in other regions; $w(\mathrm{Zn})$ in $\mathrm{S} 2$ and S3 was no significant different, but was significantly higher than that in S4. Through above analysis, the spatial distributions of all metals in the organisms were significantly different; however, the spatial tendencies were not identical to each metal. Therefore, further research should be taken to explore the relationship between organisms and environments. 

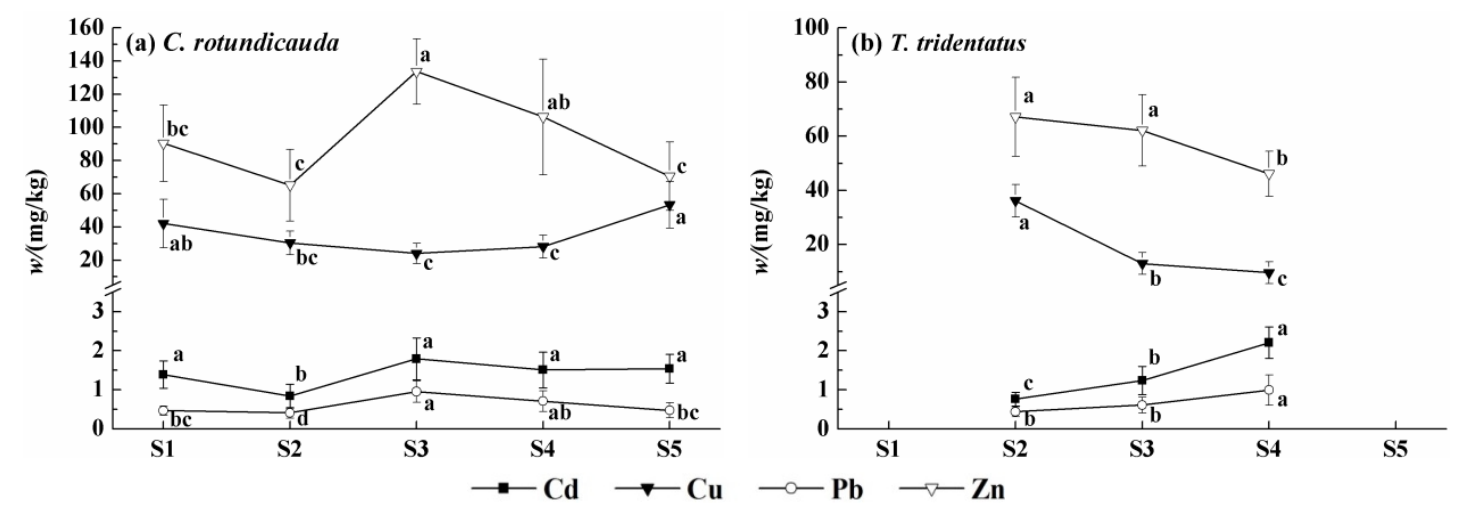

Fig.2 Spatial distribution of heavy metals in visceral mass of $C$. rotundicauda (a) and T. tridentatus (b) from the Beihai coast of Beibu Gulf

(The different letters in the same metal had significant difference, $\mathrm{p}<0.05$ )

\section{Summary}

(1) Heavy metals $(\mathrm{Cd}, \mathrm{Cu}, \mathrm{Pb}$ and $\mathrm{Zn}$ ) were all detected in different tissues of horseshoe crabs from the Beihai coast of Beibu Gulf. The variation tendency of measured metals in visceral mass was in the order of $\mathrm{Zn}>\mathrm{Cu}>\mathrm{Cd}>\mathrm{Pb}$, while that in other tissues including gill, carapace and muscle was all in the order of $\mathrm{Zn}>\mathrm{Cu}>\mathrm{Pb}>\mathrm{Cd}$. The enrichments of essential trace elements $(\mathrm{Cu}$ and $\mathrm{Zn})$ in the organisms were higher than those of non-essential trace elements $(\mathrm{Cd}$ and $\mathrm{Pb})$;

(2) The metal contents in different tissues were varied: $\mathrm{Cd}, \mathrm{Cu}$ and $\mathrm{Zn}$ contents expressed the highest enrichment in the visceral mass, carapace and muscle, while the $\mathrm{Pb}$ content in the gill was relatively high;

(3) There were significant spatial differences for all metals in the horseshoe crabs; however, the distribution tendencies were not identical to each metal. Therefore, further research should be taken to explore the relationship between organisms and environments.

\section{Acknowledgments}

This work was financially supported by the NSFC (41473118 and 41273139), Guangxi science and technology development projects (14125007-2-13) and the BaGui Scholars Program Foundation (2014).

\section{References}

[1] M. Varol: J. Hazard. Mater. Vol. 195 (2011), p. 355-364

[2] B.Y. Kamaruzzaman, B. Akbar John, M.H. Aqilah Megat and K. Zaleha: Res. J. Environ. Toxicol. Vol. 5 (2011), p. 222-228

[3] Y. Liao, F. Ye and S. Hong: Chinese J. Mar. Drugs Vol. 17 (1998), p. $34-40$ (in Chinese)

[4] K. Zaleh, B.Y. Kamaruzzaman, B. Akbar John and M.C. Ong: J. Biol. Sci. (2010)

[5] J. Burger: Environ, Monit. Assess. Vol. 46 (1997), p. 279-287

[6] J. Burger, C. Dixon, T. Shukla, N. Tsipoura and M. Gochfeld: Environ. Res. Vol. 90 (2002), p. 227-236

[7] J. Liang, J. Wang, Y. Su, D. Wang and J. Yao: Acta Ecol. Sin. Vol. 21 (2001), p. 1009-1012 (in Chinese)

[8] M. Xiao, S. Wang, F. Bao, F. Cui and J. Kang: R. Environ. Sci. Vol. 24 (2011), p. $942-948$ (in Chinese)

[9] C. Chun and Q. Zhou: J. Argo-Environ. Sci. Vol. 28 (2009), p. 425-432 (in Chinese) 